\title{
LACK OF TECHNICALLY EDUCATED GRADUATES - A THREAT TO THE CZECH ECONOMY
}

\author{
Vladimira Novakova*1 \\ ${ }^{1}$ CTU in Prague, Thakurova 7, Prague 6, 166 29, Czech Republic, vladimira.novakova@fsv.cvut.cz
}

\begin{abstract}
This paper discusses the key role of technical education at universities and presents a specific example of how to raise the expertise of the young generation and create better conditions for entering the labor market. It addresses the serious problem that young people are lacking interest in technical fields.
\end{abstract}

\section{Keywords}

Technical fields, education, competitiveness

\section{JEL Classification}

$123, J 01$

DOI: https://doi.org/10.14311/bit.2018.01.06

Editorial information: journal Business \& IT, ISSN 2570-7434, CreativeCommons license (c) (1) published by CTU in Prague, 2018, http://bit.fsv.cvut.cz/

\section{Introduction}

As emerges from the EU Science and Research Ministers report, 2020 Europe should become a place where scientists can work better together, have a good background for their research, ... make more effective use of their research potential [1]. Together, they agreed that Europe must work to strengthen the so-called knowledge triangle - education, research and innovation, which is absolutely crucial for the successful creation of the European Research Area. This report was preceded by the Declaration on Science and the Use of Scientific Knowledge, which was adopted the UNESCO World Conference on Science under the auspices of UNESCO and ICSU in 1999 in Budapest. The key role in the Declaration is played by education, in particular the promotion of scientific education and research, which is essential in the acquisition of knowledge, in the education of scientists and in public education, as well as the development of cooperation between research and development institutions, universities and industry, or investment incentives [2].

\section{Search problem}

Although it will be 10 years since the meeting in December 2018 and 20 years since the conference in Budapest next year, this initiative remains valid not only for research institutes but also for universities and colleges as a center of education. Not everywhere we have succeeded in transforming the often closed communities of intellectuals into modern companies for education. The companies that would attract young capable people and that would be able to compete on an international competitive footing with countries like Denmark, Finland, Sweden ... 


\section{Results and discussion}

Czech higher education has significantly changed for the better by supporting innovative and creative thinking, creating and implementing new educational programs, specialized courses, varied forms of learning (e-learning, distance learning, 3rd century universities, ...), closer cooperation with companies, scientific institutions or research institutes. These are the steps for universities to create a competitive advantage in the readiness of their graduates for practice. It is a way to increase the international competitiveness of the domestic economy and through the multiplier effect have a positive impact on employment.

An example of a modern concept of university studies is the Faculty of Civil Engineering of the CVUT in Prague, namely the Department of Economics and Management in Construction, which extends the scope of technical education far beyond its standards in the sphere of social sciences. Its aim is to educate scholars and emerging scientists as well-educated personalities who are open to new ideas and directions. The Department of Economics and Management in Construction is the holder of doctoral, master's and bachelor's degree courses in economics and construction management. The Department is an important provider of lifelong learning programs in the field of building management, supply systems and management of construction contracts, and provides expert services in the field of building economics and real estate valuation within the expert institute of the CVUT in Prague.

For more than 50 years, the Department has guaranteed high quality teaching as a balanced compromise between technical and social science subjects. The ratio between them is about 70:30, i.e. $70 \%$ of the students are educated as technicians, $30 \%$ as economists. As confirmed by practice, this ratio is optimal in terms of competitiveness and labor market requirements. Students obtain complete engineering education - they are able to prepare and manage large investment projects, thanks to economic education (subjects such as budgeting and calculation of building projects) are able to assess these projects from financial and economic.

The Department enables students to study economics and management (Project Management, Building Management and Management and Economics in Construction). Thanks to the systematic work of the members of the Department, the subjects are continually innovated and supplemented with the latest trends and techniques in the preparation and implementation of constructions. The subjects include European standards in order to harmonize the knowledge and skills of graduates for their possible application on the European construction market.

A subject of great interest from students is BIM - Building Information Modeling. According to [3] hundreds of organizations around the world adopted BIM and gained its benefits, met clients and users' satisfaction and increased their profits by $5-12 \%$. As the practice confirms, usage of the BIM for processing the construction work is a significant competitive advantage for businesses. They have gained new tools for visualization, coordination, early analysis of solutions, and scheduling [10].

As a powerful tool for sustainability in construction, the Building Information Modeling (BIM) has been struggling with implementation into practice for the last two decades [4]. BIM's application to Czech construction industry is a way to increase efficiency and shorten the construction time. Implementation of BIM leads to increased efficiency of work of all stakeholders in the construction work, ie designers, architects, statics and construction engineers. A skilled labor force has always been a pillar of the Czech economy. This is especially true for construction. A major problem at present is the rising age of workers in the construction of manual works as well as managers, the age is steadily rising. Implementation of BIM technology requires a change of mindset, working with the intelligent 3D BIM model puts greater demands on software and hardware than with classic 2D CAD [5]. The BIM course focuses on mastering the relevant software (Autodesk Revit a Autodesk Navisworks). 
If the students choose the project management within the master's degree program, the Department offers a range of the subjects with the use of exact methods, which are linked to the curricula of the previous bachelor's degree program. In addition to compulsory subjects such as Engineering, Quality and Risk Management, Project Design, Financial Management and Accounting, etc., students can choose from a wide range of optional subjects - Real Estate Development, Financial Markets, Psychology, Sociology, Real Estate Valuation, Security management.

Students in the field of Management and Economics in Civil Engineering graduate courses such as Financial Management and Investment, Business Management, Calculation and Offers, Human Resources, etc. They can choose from a selection of interesting subjects such as Subcontracting, Logistics, Management public procurement including all of the above.

Within the field of Building Management, which is intended for graduates of bachelor's non-economic disciplines, the Department offers courses such as Calculation and Offers, Fundamentals of Innovative Entrepreneurship, Management Theory, Financing, Investing, Contracts, Building Preparation and Management, Business Economics, Human Resources. There is a choice of optional subjects (Fundamentals of Information Modeling, Management Information Systems, Marketing and others).

Unlike graduates of economic schools, construction economists have a much wider use in practice after completing their studies. As confirmed by the construction companies, where many graduates are leaving, they are highly qualified and educated professionals. Although most of them leave to work in construction companies for senior management positions, some of them, thanks to economic education, find jobs outside the construction industry, for example in public administration or the financial sector. The combination of technical and economic education is thus confirmed as the right way to increase the employability of young people in the labor market.

\section{Survey findings}

Although the Department tries to support the innovative and creative thinking of students, to create and implement interesting educational programs, to offer specialized courses, to use new forms of education (e-learning) to create the greatest competitive advantage in the readiness of their graduates, it is increasingly affecting the all-society problem - a small interest of young people in technical fields. Despite the fact that the University maintains the status of one of the best technical universities in Europe, the loss of students logically affects it. Decreases in the number of students in various fields are recorded in Table 1.

Table 1: Students in the Czech Republic by field of education (2001-2017). Source: [6]

\begin{tabular}{|c|c|c|c|}
\hline Universities in CR & 2015 & 2016 & 2017 \\
\hline Science & 29854 & 28358 & 27550 \\
\hline Technical sciencies & 73236 & 69174 & 65352 \\
\hline Agriculture and veterinary & 13469 & 13482 & 13218 \\
\hline Health and social cre & 30988 & 31198 & 31042 \\
\hline Humanities and social sciences & 56196 & $53 \quad 167$ & 50352 \\
\hline Economic sciences & 69449 & 64510 & 60559 \\
\hline Law & 13398 & 13276 & 13618 \\
\hline Pedagogy, social sciencies & 34734 & 32868 & 31722 \\
\hline Culture and art & 9760 & 9343 & 9355 \\
\hline
\end{tabular}

Since 2010, the number of students of technical sciences has been decreasing every year. This decline corresponds to the development of the total number of university students (Bachelor, Master and Doctoral Studies) in the Czech Republic. While in 201086 thousand of students studied the technique at Czech universities, in 2017 the number of students dropped to 65 thousand (see Table 1). According to the Czech Statistical Office, the outlook for the future in this area is not positive either. Demographic 
curves showing a steady decline, significant devaluation of higher education with more than forty private universities have resulted in the number of graduates comparing the number of college posts since 2008.

The long-term low number of university graduates is not just a problem for the Czech Republic. Interest in the study of technical disciplines is long-term low across Europe as well as the USA. The opposite trend is reported by Asia - about 3/5 students are employed in the technical sciences, which is an enviable number compared to Europe, where only about $15 \%$ of pupils go to technical secondary schools. Lack of university-educated technicians is also troubled by businesses. Increasingly, it is heard from building and other industrial managers that they have a problem with getting people with technical education. According to a National Engineering Cluster survey conducted in 65 companies, about $10 \%$ of trainees, $10 \%$ of high school students and $15 \%$ of undergraduates with technical backgrounds are missing [7]. Technically educated professionals are missing more than half of Czech companies. The absence of technically skilled workers is most felt by engineering firms, according to a survey by the Czechlnvest government agency [8]. The survey was attended by 1033 owners, executives and homeowners. The survey also revealed that $42 \%$ of firms will need skilled technicians ahead of schedule and $16 \%$ of employers is a deficit now. In practice, there is the greatest lack of architects, designers, designers and engineers.

Although Czech education is at a high level in general, recent studies have confirmed the deterioration of students, particularly in cognitive knowledge. This is a consequence of the unsystematic approach in the field of education, but also the state of the Czech economy in the early 1990s. Since the technical education, both secondary and tertiary, is the alpha and omega of the Czech industry and thus the entire national economy, the state has to play a key role here. It is necessary to increase the attractiveness of the technical disciplines, to start great effective promotion of them at elementary schools. The children and their parents have to realize the prospect and good practice, whether with a vocational certificate or with a degree in the technical field.

In addition, the vocational schools need greater financial support, for example through grants and scholarships. They could buy high-quality techniques and advanced equipment to offer their students good-quality training programs with professional practices and excursions to businesses. The state should create better conditions for cooperation between educational institutions and companies. As confirmed by the Director of the EU Funds, Research and Development Department of the Ministry of Labor and Industry Petr Očko: "The closer cooperation between companies with educational institutions is the key to improving the situation in the future" [9].

\section{Conclusion}

It is undoubtedly unnecessary to recall how important it is for a small economy like the Czech Republic to support the education of the young generation in technical fields. If the economy is to be competitive and not just a cheap labor force, all forces should be put into promotion and support of technical education. The university initiative itself is not enough, it is a state that greatly influences the quality of education of the younger generation. If the radical change does not occur as soon as possible, the Czech Republic will not compete globally and become dependent on foreign knowledge and foreign technology. 


\section{References}

[1] European Union Strategy Papers 2010-2020, www.msmt.cz/file/15690_1_1

[2] NOVÁKOVÁ, V. and V. LIŠKA. The Declaration on Science and the Use of Scientific Knowledge for Lecturers. Journal on Legal and Economic Issues of Central Europe, 5-2014. No.1.,pp. 142-147. ISSN 2043-085X

[3] JERNIGAN F. BIG BIM little bim - the practical approach to building information modeling - Integrated practice did the right way! 1st Edition, Kindle Edition. [online] [19.03.2018] Available at: https://www.amazon.com/BIG-BIM-little-bim-information-ebook/dp/B0010AE7PS

[4] MATĚJKA, P.; RŮŽIČKA, J.; ŽÁK, J.; HÁJEK, P.; TOMEK, A.; KAISER, J.; VESELKA, J. The Implementation of Building Information Modeling into Educational Programs at CTU in Prague In: Central Europe towards Sustainable Building 2016 - Innovations for Sustainable Future. Praha: GRADA PUBLISHING, 2016. pp. 853-860. 1st edition, Prague, June 2016, Complete edition - printed version + Flash disk with full paper version. ISBN 978-80-271-0248-8.

[5] NOVÁKOVÁ, V., S. AHMED, and S. VITÁSEK. Problems of technical education and lack of students at Czech technical universities. In: OSADCUKS, V. and L. MALINOVSKA, eds. Engineering for Rural Development, Proceedings of 17th International Scientific Conference. 17th International Scientific Conference Engineering for Rural Development, Jelgava, 2018-05-22/2018-05-25. Jelgava: Latvia University of Agriculture, 2018. pp. 635-639. ISSN 1691-5976. DOI 10.22616/ERDev2018.17.N295. Available from: http://tf.llu.lv/conference/proceedings2018/Papers/N295.pdf

[6] The Ministry of Education, Youth and Sports. Available online at: www.msmt.cz/vzdelavani/skolstvi-vcr/statistika-skolstvi/data-o-studentech-poprvezapsanych-a-absolventech-vysokych, 2018 (In Czech)

[7] www.czechinvest.org/cgmc-klastr-obecneho-strojirenstvi

[8] www.czechinvest.org/ceske-firmy-trapi-nedostatek-technicky-kvalifikovanych-pracovniku

[9] www.euro.cz/byznys/pruzkum-vice-nez-polovine-firem-chybi-technicky-vzdelani-lide-860215

[10] Tomek, R. a Kalinichuk, S. Agile PM and BIM: A Hybrid Scheduling Approach for a Technological Construction Project. Procedia Engineering. 2015, 123s. 557-564. ISSN 1877-7058. Available at: http://www.sciencedirect.com/science/article/pii/S1877705815032099. Scopus: 2-s2.0-84953214549 